\title{
Pengaruh Penentuan Strategi Komunikasi Pemasaran Terhadap Minat Beli Masyarakat Pada Produk Lokal
}

\author{
Nur Azizah ${ }^{1}$, Putri Shafira Carolina ${ }^{2}$, Mochamad Rifqi Alfaizi ${ }^{3}$ \\ ${ }^{1}$ Program Studi Akuntansi, Fakultas Bisnis dan Ekonomika \\ ${ }^{2}$ Program Studi Teknik Industri, Fakultas Teknologi Industri \\ ${ }^{3}$ Program Studi Akuntansi, Fakultas Bisnis dan Ekonomika \\ Universitas Islam Indonesia \\ 1azizahnur1001@gmail.com, ${ }^{2}$ peesce13@gmail.com, ${ }^{3}$ rifqialfaizi3@gmail.com
}

\begin{abstract}
ABSTRAK
Budaya hidup yang mengandalkan peralatan digital untuk mencapai produktivitas kinerja menjadi salah satu dampak positif. Namun, hal itu berpengaruh negatif jika menimbulkan gaya hidup hedonisme dan pemenuhan kebutuhan karena prestige dan cepatnya informasi yang didapat. Hal ini menjadi bahasan serius bagi masyarakat dan pemerintah dalam perkembangan produk lokal khususnya pariwisata dan produk daerah yang berada dalam kondisi darurat dikarenakan banyak masyarakat yang belum mengetahuinya. Oleh karena itu, sangat diperlukan strategi komunikasi pemasaran yang tepat agar minat beli masyarakat pada produk lokal meningkat. Tujuan Penelitian ini untuk mengetahui (1) pengaruh perilaku konsumen, promosi media sosial, Green Marketing terhadap minat masyarakat dalam mengonsumsi produk lokal, (2) pengaruh strategi marketing terhadap minat beli masyarakat, (3) strategi komunikasi pemasaran yang tepat, dampak positif, serta hambatan penerapannya untuk meningkatkan minat masyarakat untuk menggunakan produk lokal. Jenis penelitian ini adalah penelitian eksplanatori dengan pendekatan kuantitatif. Metode penelitian ini menggunakan teknik pengumpulan data kuesioner yang disebarkan melalui Google forms. Analisis data yang digunakan adalah analisis regresi linier berganda dan analisis komparatif. Hasil penelitian ini menunjukkan bahwa (1) perilaku konsumen berpengaruh positif dan tidak signifikan terhadap minat beli produk lokal, (2) promosi media sosial berpengaruh positif dan tidak signifikan terhadap minat beli produk lokal, (3) green marketing berpengaruh positif dan signifikan terhadap minat beli produk lokal, (4) perilaku konsumen, promosi media sosial, dan green marketing secara bersama-sama berpengaruh signifikan terhadap minat beli produk lokal oleh masyarakat Indonesia. Hasil penelitian ini juga menunjukkan bahwa green marketing adalah strategi komunikasi pemasaran yang sangat tepat digunakan untuk meningkatkan minat beli produk lokal.
\end{abstract}

Kata Kunci : green marketing, produk lokal, minat beli, perilaku konsumen, promosi media sosial

\begin{abstract}
A living culture that relies on digital equipment to achieve performance is one of the positive impacts. However, it negatively affects if it causes a hedonistic lifestyle and fulfillment of needs because of the prestige and speed of information obtained. This is a severe discussion to the community and government in developing local products, especially tourism and regional products that are in an emergency condition because many people don't know about it. Therefore, it is necessary to have an appropriate marketing communication strategy to increase people's buying interest in local products. The purpose of this study was to know (1) the influence of consumer behavior, social media promotion, Green Marketing on people's interest in the consumption of local products, (2) the influence of marketing strategies on people's buying interest, (3) the right marketing strategy, positive impact, and barriers. Its application is to increase public interest in using local products. This type of research is a descriptive study with a quantitative approach. The research method uses a questionnaire data analysis technique that is distributed via Google forms. The data analysis used is multiple linear regression analysis and comparative analysis. The results of this study indicate that (1) behavior has a positive and insignificant effect on local buying interest, (2) promotional media has a positive and insignificant effect on buying interest in local products, (3) green marketing has a positive and significant effect on buying interest in local products, (4) consumer behavior, promotional media, and green marketing together significantly affect the buying interest of local products by the Indonesian people. The results of this study also indicate that green marketing is a very appropriate marketing communication strategy to increase interest in buying local products.
\end{abstract}

Keywords: green marketing, local products, purchase interest, consumer behavior, social media promotion 


\section{PENDAHULUAN}

Budaya hidup yang mengandalkan peralatan digital memiliki dampak positif karena dapat memudahkan manusia untuk mencapai produktivitas kinerja. Namun, hal itu juga berpengaruh negatif karena dapat menimbulkan gaya hidup hedonisme dan pemenuhan kebutuhan yang dikarenakan prestige dan kecepatan untuk mendapat informasi. Banyak produk impor yang dikonsumsi masyarakat dibuktikan dari data BPS 2019, bahwa nilai impor barang di Indonesia meningkat sebanyak $12,25 \%$ dari bulan sebelumnya. Hal ini disebabkan oleh gencarnya promosi produk luar negeri dalam sosial media yang dilakukan secara masif. Banyaknya impor yang masuk ke dalam negeri akan berpengaruh koreksi negatif pada neraca transaksi berjalan terhadap nilai ekspor. Produk lokal dapat dikatakan kalah saing dengan produk luar negeri. Ada juga pengaruh hal tersebut yaitu produk luar negeri memiliki brand sebelum memasuki pasar di Indonesia, pengalaman ekspansi, kekuatan modal yang dimiliki, dan strategi komunikasi marketing yang digunakan. Strategi komunikasi merupakan panduan perencanaan untuk mencapai suatu tujuan atau dapat juga dikatakan proses dasar dengan dimulai dari bentuk komunikasi sederhana sampai bentuk komunikasi elektronik.

Salah satu inovasi yang dilakukan adalah pengalihan strategi dari televisi dan koran dengan melakukan promosi di media sosial demi menjangkau pangsa pasar milenial. Perusahaan-perusahaan juga mulai beradaptasi dan mulai memahami keinginan konsumen yang dibutuhkan. Perusahaan juga harus membangun reputasi yang dapat dikenal dan mendapatkan hati di konsumennya. Membangun reputasi bukanlah hal yang mudah tetapi hal itu merupakan langkah yang penting untuk perusahaan karena reputasi harus dibangun dengan kesungguhan dan butuh kerja sama tim yang solid. Salah satu cara membangun reputasi adalah dengan cara melakukan langkah-langkah marketing yang berbeda dari yang lain yaitu Green Marketing. Green Marketing yang diterapkan perusahaan diharapkan akan membentuk sebuah dorongan untuk membeli suatu produk (Agustin, 2015:3). Hal ini selanjutnya menjadi panutan dalam mengakomodasi perilaku konsumen, sehingga mempengaruhi keputusan pembelian. Perusahaan yang menerapkan konsep Green Marketing tentunya akan lebih banyak dicari dan disukai oleh konsumen, khususnya konsumen yang selektif dalam pembelian produk ramah lingkungan. Konsep komunikasi pemasaran ini sangatlah strategis, sehingga dapat meningkatkan minat masyarakat dalam membeli produk lokal. Oleh karena itu, peneliti akan meneliti mengenai faktor-faktor yang mempengaruhi minat beli masyarakat pada produk lokal dan strategi yang tepat untuk meningkatkan minat masyarakat tersebut.

\section{METODE PENELITIAN}

Metode penelitian yang digunakan yaitu penelitian kuantitatif. Adapun jenis penelitiannya adalah penelitian deskriptif korelasional. Jenis penelitian ini mempelajari hubungan dua variabel atau lebih, sejauh mana antar variabel berhubungan dengan variasi dalam variabel lain sesuai dengan gejala, peristiwa, dan kejadian yang terjadi pada saat sekarang. Pemilihan metode ini digunakan untuk mengkaji hubungan penentuan strategi komunikasi pemasaran terhadap minat beli masyarakat pada produk lokal. Variabel dependen $(\mathrm{Y})$ yaitu minat beli masyarakat dan variabel independen (X) yaitu perilaku konsumen (X1), promosi media sosial (X2), dan green marketing (X3). Data yang digunakan adalah data primer. Metode pengumpulan yang digunakan yaitu kuesioner/angket atau seperangkat pernyataan-pernyataan tertulis yang diajukan kepada responden untuk dijawab.

\section{KAJIAN PUSTAKA \\ Konsep Komunikasi Pemasaran}

Komunikasi adalah suatu proses penyampaian informasi dari seseorang sebagai komunikator yang menyampaikan stimulus dengan tujuan untuk mengubah atau membentuk perilaku orang lain (Syahputra, 2013:292). Dalam komunikasi manusia dapat memberi stimulusnya dengan berbagai ragam bentuk seperti kata-kata yang secara langsung diucapkan atau melalui telepon seluler, koran, dan media komunikasi lainnya. Stimulus respons dapat diterapkan dalam komunikasi massa yang bertujuan untuk memberikan perubahan perilaku pada masyarakat luas, 
seperti halnya strategi pemasaran yang melakukan hal tersebut dengan tujuan untuk membangun popularitas dan mendongkrak minat beli masyarakat terhadap produk tersebut.

Pemasaran telah didudukkan secara strategis pada proses bisnis, dengan memilih pasar yang tepat, pengelolaan usaha yang efektif, juga didukung dengan efektivitas komunikasi pemasaran dapat membantu proses bisnis berjalan dengan baik secara signifikan. Jika dijalankan dengan baik komunikasi dapat menjadi tombak dalam melakukan pemasaran, karena komunikasi mampu menggugah minat masyarakat yang menjadi target tergerak untuk melakukan pembelian. Dengan strategi komunikasi pemasaran yang baik mencakup penggunaan teknik, memberikan informasi yang sesuai, juga pengaruh yang diinginkan dari pelaksanaan tersebut yang dilakukan oleh suatu perusahaan akan tercapai (Chrismardani, 2014:178).

\section{Perilaku Konsumen}

Perilaku konsumen merupakan bagian dari kegiatan perekonomian, untuk memahami perilaku masyarakat dalam membeli barang atau jasa diperlukan studi dan penelitian yang lebih lanjut. Perilaku konsumen adalah kegiatan-kegiatan individu yang secara langsung terlibat dalam mendapatkan dan mempergunakan barang-barang dan jasa-jasa termasuk di dalam proses pengambilan keputusan pada persiapan dan penentu kegiatan-kegiatan tersebut (Swastha, 2000:27).

Konsumen membeli barang atau jasa bertujuan untuk memuaskan keinginan dan kebutuhan yang ada pada dalam diri konsumen. Keinginan dan kebutuhan merupakan hal yang berbeda. Kebutuhan adalah sifat naluri yang dimiliki oleh seseorang demi melanjutkan kehidupannya, sedangkan keinginan adalah kebutuhan yang hadir secara tiba-tiba yang tercipta dari nafsu dan lingkungan seseorang. Banyak faktor yang mempengaruhi seseorang dalam memenuhi keinginan dan kebutuhannya, seperti jenis produk yang ada di pasaran, faktor ekonomi, psikologis, sosiologis, antropologi, budaya, dan adat istiadat. Faktor budaya yang berbeda akan membentuk perilaku konsumen yang berbeda. Orang akan cenderung berminat pada suatu produk yang memiliki kesamaan dengan budayanya. Dari minat ini akan muncul perilaku yang ditunjukkan dalam kegiatan sehari-hari.

\section{Green Marketing}

Green Marketing merupakan salah satu praktik pemasaran yang mengangkat isu-isu lingkungan. Proses kegiatan produksi yang dilakukan oleh perusahaan sering menimbulkan dampak kerusakan lingkungan, sehingga Green Marketing ini dianggap sebagai inovasi terhadap masalah tersebut. Istilah Green Marketing mulai diperkenalkan pada akhir tahun 1980an dan awal 1990-an oleh American Marketing Association (AMA) yang menyelenggarakan workshop perdana dengan tema "ecological marketing" (Triana, 2017:3). Tujuan dari Green Marketing bukan hanya melihat keuntungan sebagai tujuan utama perusahaan tetapi juga adanya tambahan kepedulian terhadap lingkungan hidup. Perusahaan diharap dapat mendorong kebiasaan baik konsumen untuk peduli terhadap lingkungan, seperti menghemat kertas, menggunakan kertas bekas, dan menghemat energi. Selain itu, perusahaan mampu mengubah budaya konsumen untuk lebih peduli terhadap lingkungan karena kesadarannya sendiri tanpa pengaruh produk perusahaan.

\section{Strategi Green Marketing}

Keputusan seorang konsumen dalam menentukan pilihan untuk membeli atau tidak membeli suatu produk atau jasa akan sangat penting bagi pergerakan pasar dan berperan penting bagi perusahaan untuk memasarkan produk-produk yang baru dikeluarkan. Keputusan ini dapat menjadi acuan seberapa efektif dan berhasilnya strategi pemasaran yang dirasa cukup bijaksana, berwawasan luas, dan tepat sasaran. Oleh karena itu, produsen sangat tertarik dengan proses pengambilan keputusan yang dilakukan oleh konsumen dalam memilih suatu produk atau jasa yang akan dipilih. Dalam mengambil keputusan produsen harus menyediakan lebih dari satu alternatif kepada konsumen yang telah disasarkan sebelumnya. 
Perusahaan harus memahami kerangka berpikir konsumen karena perusahaan memiliki tujuan untuk memberitahu dan menggambarkan kepada konsumen untuk dapat mengenali iklan, mengingat, menyukai, dan membeli produk yang telah dipasarkan Kerangka berpikir merupakan hasil dari proses untuk memperoleh pengetahuan dan pengalaman. Pengetahuan dan pengalaman yang dimiliki dan dialami oleh seseorang akan mengakibatkan perubahan pada sikap dan perilaku yang cenderung permanen. Setelah perusahaan memahami kerangka berpikir konsumen, langkah selanjutnya adalah membuat pemangsaan pasar. Ada pula prosedur untuk pemangsaan pasar antara lain adalah identifikasi pemakaian kelas sosial dari produk, perbandingan variabel kelas sosial untuk pemangsaan dengan variabel lain, deskripsi karakteristik kelas sosial yang mengidentifikasikan di dalam target pasar, dan perkembangan program pemasaran untuk memaksimumkan keefektifan bauran pemasaran yang didasarkan pada konsistensi dengan sifat kelas sosial (Engel, 1973:141)

\section{Minat Beli}

Minat beli merupakan daya tarik konsumen terhadap suatu produk barang atau jasa atau dapat pula diartikan sebagai tahap terakhir dari suatu proses keputusan pembelian yang kompleks. Hasil evaluasi ini yang akhirnya memunculkan niat atau intensi untuk membeli sebelum akhirnya konsumen benar-benar melakukan pembelian. Empat tahapan tersebut dikenal dengan model AIDA, yaitu: Attention, Interest, Desire dan Action (Kotler, 2008:12):

1. Attention. Tahap ini merupakan tahap awal dalam menilai suatu produk atau jasa sesuai dengan kebutuhan calon pelanggan, selain itu calon pelanggan juga mempelajari produk atau jasa yang ditawarkan.

2. Interest. Dalam tahap ini calon pelanggan mulai tertarik untuk membeli produk atau jasa yang ditawarkan, setelah mendapatkan informasi yang lebih terperinci mengenai produk atau jasa yang ditawarkan.

3. Desire. Calon pelanggan mulai memikirkan serta berdiskusi mengenai produk atau jasa yang ditawarkan, karena hasrat dan keinginan untuk membeli mulai timbul. Dalam tahapan ini calon pelanggan sudah mulai berminat terhadap produk atau jasa yang ditawarkan. Tahap ini ditandai dengan munculnya minat yang kuat dari calon pelanggan untuk membeli dan mencoba produk atau jasa yang ditawarkan.

4. Action. Pada tahap ini calon pelanggan telah mempunyai kemantapan yang tinggi untuk membeli atau menggunakan produk atau jasa yang ditawarkan.

\section{MODEL HIPOTESIS}

Menurut (Achmadi, 2008:50), hipotesis merupakan dugaan sementara yang masih dibuktikan kebenarannya melalui suatu penelitian. Hipotesis dirumuskan sebagai berikut:

H1 : Perilaku konsumen berpengaruh signifikan terhadap minat beli produk lokal.

$\mathrm{H} 2$ : Promosi media sosial berpengaruh signifikan terhadap minat beli produk lokal.

H3 : Green Marketing berpengaruh signifikan terhadap minat beli produk lokal.

H4 : Perilaku konsumen, promosi media sosial, dan Green Marketing secara bersama-sama berpengaruh signifikan terhadap minat beli produk lokal oleh masyarakat Indonesia.

\section{HASIL DAN PEMBAHASAN \\ Populasi dan Sampel Penelitian}

Populasi yang digunakan dalam penelitian ini adalah masyarakat umum. Sampel dipilih dengan menggunakan Quota Sampling dengan jumlah observasi sebanyak 158 orang.

Tabel 1 Data Sampel

\begin{tabular}{|c|r|r|}
\hline Umur & \multicolumn{1}{|c|}{ Jumlah } & \multicolumn{1}{c|}{ Presentase } \\
\hline 18-20 Tahun & 96 & $60.76 \%$ \\
\hline 20 s/d 25 Tahun & 46 & $29.11 \%$ \\
\hline
\end{tabular}




\begin{tabular}{|c|r|r|}
\hline 26 s/d 30 Tahun & 2 & $1.27 \%$ \\
\hline 31 s/d 40 Tahun & 5 & $3.16 \%$ \\
\hline 41 s/d 52 Tahun & 9 & $5.70 \%$ \\
\hline Klasifikasi Umur & Jumlah & Presentase \\
\hline Remaja & 142 & $89.87 \%$ \\
\hline Dewasa & 16 & $10.13 \%$ \\
\hline Pekerjaan & Jumlah & Presentase \\
\hline Pelajar & 3 & $1.90 \%$ \\
\hline Mahasiswa & 136 & $86.08 \%$ \\
\hline Translator & 1 & $0.63 \%$ \\
\hline Seniman & 2 & $1.27 \%$ \\
\hline Dosen & 6 & $3.80 \%$ \\
\hline Guru & 2 & $1.27 \%$ \\
\hline Wirausahawan & 6 & $3.80 \%$ \\
\hline Karyawan BUMN & 2 & $1.27 \%$ \\
\hline Pendidikan Terakhir & Jumlah & Presentase \\
\hline SMP/Sederajat & 2 & $1.27 \%$ \\
\hline SMA/Sederajat & 140 & $10,13 \%$ \\
\hline Universitas/Perguruan Tinggi & 16 & . \\
\hline Jespond dala & & \\
\hline
\end{tabular}

Jumlah responden dalam penelitian ini didominasi oleh mahasiswa. Fakta ini dapat dipahami karena pelajar atau mahasiswa lebih paham mengenai strategi pemasaran produkproduk yang sering dikonsumsi dan sering dipublikasikan di media sosial. Dalam penelitian ini didominasi usia responden antara 18-20 tahun (60,76\%) dan 20-25 tahun $(29,11 \%)$. Sedangkan kelompok usia responden yang paling sedikit adalah kelompok usia diatas 26 tahun. Jumlah responden terbanyak berdasarkan tingkat pendidikan adalah SMA/sederajat $(88,61 \%)$. Hal ini wajar karena mayoritas responden berasal dari kalangan mahasiswa sebesar 86,08\% yang mengetahui banyak informasi terbaru mengenai pemasaran produk impor yang marak dipublikasikan melalui media. Hal yang sama terjadi pada responden berdasarkan pekerjaan yaitu mahasiswa sebesar $86,08 \%$.

\section{Analisis Data}

1. Hasil pengujian asumsi Klasik

Sebelum dilakukan pengujian hipotesis, terlebih dahulu dilakukan pengujian untuk memenuhi persyaratan dan memperoleh penaksiran yang terbaik. Adapun uji yang dilakukan dalam penelitian ini adalah uji normalitas, multikolinearitas, autokorelasi, dan heteroskedastisitas.

a. Uji Normalitas

Uji ini bertujuan untuk menguji apakah dalam model regresi ini, terdapat variabel pengganggu atau residual. Uji ini menggunakan kaidah keputusan jika signifikansi $>$ dari $\alpha=0,05$ maka dapat disimpulkan bahwa data tersebut berdistribusi normal. Berdasarkan hasil pengujian, jumlah observasi Kolmogrov Smirnov dalam penelitian ini sebesar 158. Pengujian menunjukkan bahwa variabel memiliki nilai distribusi sebesar 0,462 yang berarti nilainya normal karena lebih dari 0,05 .

b. Uji Autokorelasi

Uji autokorelasi bertujuan untuk mengetahui pola pengaruh variabel bebas. Regresi berganda ini digunakan untuk mengetahui pengaruh variabel perilaku masyarakat, promosi media sosial, dan Green Marketing terhadap variabel terikat minat beli produk lokal. Berdasarkan 
pengujian, dw test untuk observasi (n) sebanyak 353, variabel independen (k) sebanyak 3 variabel, nilai durbin watson dengan $\alpha=0,05$ diperoleh nilai $\mathrm{dl}=1,7014 \mathrm{dan} \mathrm{du}=1,7787$. Maka nilai $\mathrm{du}<\mathrm{dw}<4-\mathrm{du}(1,7014<2,115<2,221)$ berarti dapat disimpulkan bahwa tidak terdapat gejala autokorelasi pada data.

c. Uji Multikolinearitas

Uji Multikolinearitas bertujuan untuk menguji apakah di dalam model regresi ditemukan adanya korelasi antar variabel bebas. Multikolineritas terjadi jika nilai VIF $>10$, dan jika tolerance $<0,1$. Dari hasil analisis program SPSS 21, pada bagian koefisien ketigas variabel independen terlihat bahwa nilai tolerance dari variabel struktur aktiva dari variabel perilaku konsumen 0,777 ; promosi media sosial 0,736; dan Green Marketing 0,677. Nilai tolerance ketigas variabel independen dapat disimpulkan bahwa nilai tolerance bebas multikolinearitas, karena $>0,1$. Sedangkan nilai VIF perilaku konsumen 1,287; promosi media sosial 1,358; dan Green Marketing 1,477. Nilai VIF ketiga variabel independen dapat disimpulkan bahwa nilai VIF bebas multikolinearitas, karena nilai VIF ketiga variabel < 10. Dari nilai-nilai tersebut dapat disimpulkan bahwa model regresi penelitian ini bebas dari masalah multikolinearitas.

Tabel 2 Hasil Uji Multikorelasi

Hasil Uji Multikolinearitas

\begin{tabular}{|l|l|l|c|r|r|}
\hline \multirow{2}{*}{ Model } & \multicolumn{2}{|c|}{$\begin{array}{c}\text { Unstandardized } \\
\text { Coefficients }\end{array}$} & $\begin{array}{c}\text { Standardized } \\
\text { Coefficients }\end{array}$ & \multicolumn{2}{c|}{$\begin{array}{c}\text { Collinearity } \\
\text { Statistics }\end{array}$} \\
\cline { 2 - 6 } & B & Std. Error & Beta & Tolerance & VIF \\
\hline (Constant) &, 687 &, 311 & & & \\
X1 &, 067 &, 056 &, 071 &, 777 & 1,287 \\
X2 &, 083 &, 082 &, 062 &, 736 & 1,358 \\
X3 &, 684 &, 063 &, 690 &, 677 & 1,477 \\
\hline
\end{tabular}

Keterangan:

$\mathrm{Y}=$ Minat Beli produk lokal

$\mathrm{X} 1=$ Perilaku Konsumen

$\mathrm{X} 2=$ Promosi dengan Media Sosial

X3 = Green Marketing

2. Uji Hipotesis

a. Uji F (Uji Simultan)

Uji ini digunakan untuk mengetahui apakah terdapat pengaruh antara variabel perilaku konsumen, promosi media sosial, dan Green Marketing secara bersama-sama (simultan) terhadap variabel minat beli produk lokal. Untuk lebih jelasnya, hasil perhitungan dapat dilihat pada tabel berikut :

Tabel 3 Uji Simultan

Koefisien Determinasi $(\mathbf{F})$

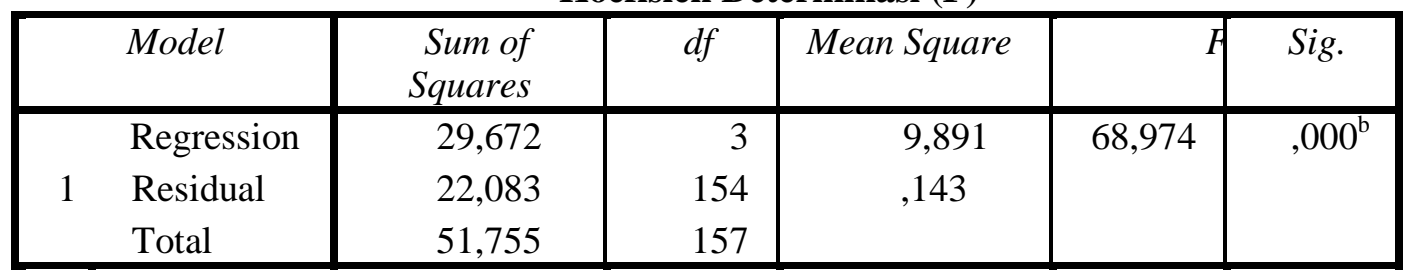

a. Dependent Variable: Y1

b. Predictors: (Constant), X3, X1, X2

Berdasarkan hasil perhitungan dengan menggunakan SPSS 21, diperoleh nilai signifikansi sebesar 0,000 dan signifikan pada 0,05. Dapat disimpulkan bahwa perilaku konsumen, promosi media sosial, dan Green Marketing secara bersama-sama berpengaruh signifikan terhadap variabel minat beli produk lokal. 
Tabel 4 Uji R

Uji R

\begin{tabular}{|c|r|r|r|r|}
\hline Model & $R$ & $R$ Square & $\begin{array}{c}\text { Adjusted } R \\
\text { Square }\end{array}$ & $\begin{array}{c}\text { Std. Error of the } \\
\text { Estimate }\end{array}$ \\
\hline 1 &, $757^{\mathrm{a}}$ &, 57 &, 565 &, 37868 \\
\hline
\end{tabular}

a. Predictors: (Constant), X3, X1, X2

b. Dependent Variable: Y1

Koefisien determinasi $\left(\mathrm{R}^{2}\right)$ digunakan untuk mengetahui kesesuaian atau ketepatan antara nilai dugaan atau garis regresi dengan data sampel. Nilai koefisien determinasi antara nol dan satu. Nilai $\mathrm{R}^{2}$ yang mendekati 0 menunjukkan bahwa variasi variabel dependen terbatas. Sedangkan jika nilai $\mathrm{R}^{2}$ mendekati 1 menunjukkan bahwa variabel-variabel independen dapat memberikan semua informasi yang dibutuhkan untuk memprediksi variabel dependen. Berdasarkan dari uji regresi linier berganda terhadap model penelitian dengan menggunakan variabel debt to equity ratio diperoleh nilai adjusted $\mathrm{R}^{2}$ sebesar 0,565 atau sebesar $56,5 \%$. Sedangkan $\mathrm{R}^{2}$ nya sebesar 0,573 atau $57,3 \%$. Dengan demikian maka dapat disimpulkan bahwa 57,3\% variabel- variabel minat beli produk lokal mampu diklasifikasikan oleh perilaku konsumen, promosi media sosial, dan Green Marketing sedangkan sisanya sebesar 42,7\% dijelaskan oleh variabel-variabel lain di luar model.

b. Uji T (Uji Parsial)

Penelitian ini memiliki 3 (tiga) hipotesis yang diuji untuk melihat pengaruh perilaku konsumen, promosi media sosial, dan Green Marketing.

Tabel 5 Hasil Uji T

Hasil Pengujian Hipotesis

\begin{tabular}{|l|r|r|r|r|r|}
\hline \multirow{2}{*}{ Model } & \multicolumn{2}{|c|}{$\begin{array}{c}\text { Unstandardized } \\
\text { Coefficients }\end{array}$} & $\begin{array}{c}\text { Standardized } \\
\text { Coefficients }\end{array}$ & \multicolumn{1}{c|}{ Sig. } \\
\cline { 2 - 6 } & \multicolumn{1}{|c|}{$\mathrm{B}$} & \multicolumn{1}{c|}{ Std. Error } & \multicolumn{1}{c|}{ Beta } & & \\
\hline (Constant) &, 687 &, 311 & & 2,212 &, 028 \\
X1 &, 067 &, 056 &, 071 & 1,186 &, 237 \\
X2 &, 083 &, 082 &, 062 & 1,017 &, 311 \\
X3 &, 684 &, 063 &, 690 & 10,783 &, 000 \\
\hline
\end{tabular}

a. Dependent Variable: Y1

Adapun persamaan regresi yang didapatkan berdasarkan tabel tersebut adalah sebagai berikut : $\mathrm{Y}=0,687+0,067 \mathrm{X} 1+0,083 \mathrm{X} 2+0,684 \mathrm{X} 3$

Uji regresi linear berganda pada tahap ini dilakukan dengan tingkat signifikansi $\leq 0,05$, apabila terdapat variabel bernilai $\geq 0,05$ maka variabel bebas tersebut tidak memiliki pengaruh terhadap variabel yang terikat.

1. Hasil Pengujian Hipotesis 1 dan Pembahasan

Berdasarkan hasil perhitungan dengan menggunakan program SPSS 21 seperti terlihat pada Tabel di atas, variabel perilaku konsumen memiliki t hitung sebesar 1,186 dan nilai signifikan sebesar 0,237. Ketentuan pengambilan keputusan hipotesis diterima atau ditolak didasarkan pada besarnya nilai signifikansi. Jika signifikansi lebih kecil atau sama dengan $0,05(\leq 0,05)$ maka hipotesis diterima. Hasil penelitian diperoleh nilai signifikansi sebesar $0,237>0,05$; maka disimpulkan bahwa hipotesis (H1) yang berbunyi "Perilaku konsumen berpengaruh signifikan terhadap minat beli produk lokal", ditolak. Hasil penelitian ini menunjukkan bahwa perilaku konsumen tidak berpengaruh signifikan terhadap minat beli produk lokal. Perilaku konsumen adalah tindakan pembeli dalam mengonsumsi suatu produk yang tidak didasari hanya pada pendapatan atau gaya hidup, tetapi juga sebagai 
bentuk manifestasi bela negara atau kualitas dari produk tertentu. Sehingga perilaku konsumen tersebut tidak berpengaruh signifikan terhadap minat beli produk lokal. Hasil penelitian ini sejalan dengan penelitian Setiawan (2014:46) dan Siswanto (2017:102) yang menyatakan perilaku konsumen tidak berpengaruh terhadap produk lokal.

2. Hasil Pengujian Hipotesis 2 dan Pembahasan

Variabel Promosi Media Sosial memiliki t hitung sebesar 1,017 dan nilai signifikansi sebesar 0,311 pada tingkat signifikansi 0,05. Dapat disimpulkan bahwa 0,311>0,05 maka Hipotesis (H2) yang berbunyi "Promosi media sosial berpengaruh signifikan terhadap minat beli produk lokal." ditolak. Hasil dalam penelitian ini menunjukkan bahwa promosi media sosial tidak berpengaruh signifikan terhadap minat beli produk lokal. Promosi dengan menggunakan media sosial memang dianggap sebagai salah satu strategi marketing yang memiliki dampak besar terhadap masyarakat. Namun, promosi dengan media sosial ini kurang berdampak terhadap minat beli masyarakat untuk membeli produk lokal. Promosi dengan menggunakan media sosial tidak selalu meningkatkan minat beli produk lokal, tetapi tergantung pada konten promosi tersebut. Cara dan konten yang dipaparkan dalam pemasaran oleh produk luar negeri lebih gencar dan mengangkat brand dan iklan yang menarik. Produk luar negeri lebih cenderung mempromosikan produknya dengan mengangkat isu-isu masalah yang sedang terjadi di masyarakat sehingga hal itu menjadikan produk tersebut sebagai problem solving. Oleh karena itu, memungkinkan pengaruhnya terhadap produk lokal tidak besar, dikarenakan promosi produk lokal kurang menggunakan strategi komunikasi marketing yang tepat dibanding produk luar negeri . Hasil penelitian ini sejalan dengan penelitian Imon, Tumbel, dan Mandagie (2018:1315) yang menyatakan bahwa strategi pemasaran dengan kualitas pelayanan/cara komunikasi yang kurang tepat menjadi faktor kegagalan. Oleh karena itu, promosi media sosial tidak berpengaruh signifikan terhadap minat beli produk lokal karena tergantung pada strategi komunikasi yang digunakan.

3. Hasil Pengujian Hipotesis 3 dan Pembahasan

Variabel Green Marketing memiliki t hitung sebesar 10,783 dan nilai signifikansi sebesar 0,000 pada tingkat signifikansi 0,05. Dapat disimpulkan bahwa 0,000 $<0,05$ maka Hipotesis (H3) yang berbunyi "Green Marketing berpengaruh signifikan terhadap minat beli produk lokal.", diterima. Hasil dalam penelitian ini menunjukkan bahwa Green Marketing menjadi strategi pemasaran yang dapat meningkatkan minat masyarakat untuk mengonsumsi produk lokal. Strategi marketing ini mengangkat isu-isu lingkungan sebagai konten atau pokok bahasan dalam iklannya. Pemasaran dengan strategi ini lebih interaktif dibandingkan dengan strategi komunikasi pemasaran yang lain. Hasil penelitian ini sesuai dengan Pancoro dan Zuliestiana (2018:6) yang menjelaskan bahwa green marketing berpengaruh signifikan terhadap minat beli masyarakat.

\section{Strategi Penerapan Komunikasi Pemasaran}

Berdasarkan penelitian tersebut, konsep strategi marketing sangat berpengaruh terhadap minat beli produk lokal, yaitu dengan konsep Green Marketing untuk meningkatkan minat beli masyarakat terhadap produk lokal, sehingga perlu adanya strategi dalam penerapannya yaitu :

1. Menerapkan konsep green consumer sebagai icon produk.

Kerusakan lingkungan yang terjadi beberapa tahun belakang menjadi pembahasan isu yang menarik perhatian masyarakat secara luas. Isu ini semakin berkembang secara pesat karena didukung banyaknya media yang menyoroti dan mengkritisi dampak kerusakan lingkungan yang disebabkan oleh oknum yang tidak bertanggung jawab. Selain itu, pertumbuhan pengguna media sosial yang begitu masif akan membuat informasi semakin mudah didapatkan dan disebarkan oleh semua orang. Sehingga, perusahaan harus mulai mengampanyekan mengenai kerusakan-kerusakan alam yang diakibatkan oleh kesalahan yang dilakukan umat manusia yang tidak bertanggung jawab dan harus diperbaiki secara bersama-sama untuk merancang dan menciptakan kehidupan yang lebih baik dan berkualitas untuk masa mendatang. Hal ini dilakukan agar mendukung gerakan-gerakan yang dilakukan 
dalam media sosial dan meyakinkan bahwa perusahaan akan serius memperbaiki proses dalam perusahaan. Orang-orang yang telah memiliki perasaan dan kesadaran untuk memperbaiki dan merawat lingkungan untuk menjadi lebih baik disebut green consumer atau konsumen hijau. Green consumer atau konsumen hijau sering dibahas dalam bidang manajemen pemasaran dan perilaku konsumen. Konsumen hijau memiliki peran yang sangat penting dalam meningkatkan permintaan terhadap produk-produk yang ramah lingkungan. Tidak sedikit konsumen yang semakin berhati-hati dan selektif dalam memilih suatu produk yang disebabkan adanya rasa khawatir akan dampak yang ditimbulkan oleh kerusakan lingkungan dan munculnya kesadaran untuk mulai memperbaiki dan merawat lingkungan yang dimulai dari memilih produk untuk dibeli . (Sri Rahayu, 2017:267)

2. Menerapkan konsep produk ramah lingkungan yang akan dipublikasikan melalui media.

Perusahaan yang memproduksi produk ramah lingkungan harus memiliki konsep yang diimplementasikan secara baik agar produk yang dihasilkan sesuai dengan tujuan awal perusahaan dalam memproduksi produk. Produk yang dihasilkan tidak boleh berbahaya bagi manusia dan tidak menghasilkan limbah yang berbahaya bagi lingkungan yang akan berdampak pada makhluk hidup disekitarnya, sumber daya yang digunakan harus digunakan secara efisien sehingga tidak boros dalam penggunaan sumber daya, dan dalam proses produksi dilarang keras melakukan kekejaman pada binatang (Kasali, 2005:9). Perusahaan dapat melakukan promosi langsung kepada konsumen dengan cara menjual produk-produk ramah lingkungan terbaru dengan menggunakan potongan harga di dalam produk yang dijual secara langsung dan memberikan ucapan terima kasih terhadap produk yang telah dibeli. Hal ini akan menunjukan bahwa produk kita berbeda dari perusahaan pesaing, sehingga akan mendapatkan kepercayaan konsumen dan menjangkau pangsa pasar yang lebih luas. Acuan dalam menerapkan strategi ini adalah banyaknya orang yang tertarik dan mulai membeli produk yang ditawarkan.

3. Mengembangkan aspek komunikasi terintegrasi antara produk dan isu lingkungan

Strategi pemasaran dan slogan yang akan dipakai oleh harus sesuai dengan program yang sebelumnya telah diuji coba dan disepakati bersama. Program-program tersebut harus dikomunikasikan secara berkelanjutan dan konsisten kepada pelanggan. (Osiyo, 2018:8). Jika program-program yang dijalankan sesuai dengan rencana dan dapat dipertanggungjawabkan, maka dapat menciptakan gerakan yang masif dalam pembaharuan lingkungan dan mendukung produk-produk ramah lingkungan. Untuk menciptakan gerakan yang masif diperlukannya peran komunikasi yang efektif dan tepat sasaran. Hal ini dapat didukung dengan penggunaan media sosial dan menyebarkan pesan-pesan yang mengajak pada perilaku menjaga dan memperbaiki lingkungan. Peran komunitas juga dapat digunakan oleh perusahaan untuk menawarkan produk-produk terbaru yang berbeda dari sebelumnya. Hasil yang didapatkan oleh perusahaan adalah dapat membuat peta konsumen yang sesuai dengan produk yang akan diluncurkan dan terdapat tempat yang sudah memiliki pemikiran dan perasaan yang sama untuk memperkenalkan produk ramah lingkungan yang terbaru.

\section{Dampak Positif Strategi Penerapan Komunikasi Pemasaran}

Penerapan strategi pemasaran menggunakan Green Marketing memiliki dampak yang positif bagi perusahaan maupun masyarakat untuk meningkatkan produk lokal, yaitu :

1. Meningkatkan minat beli produk lokal.

Dengan menggunakan strategi Green Marketing perusahaan dapat meningkatkan minat beli konsumen, hal ini didukung dengan upaya perusahaan melakukan publikasi kegiatan ramah lingkungan dan melakukan inovasi pemasaran yang mengangkat isu lingkungan (Wisana, 2018:202).

2. Menambah nilai jual produk lokal.

Strategi Green Marketing dapat menambahkan nilai jual karena aktivitas Green Marketing dapat mempengaruhi reputasi perusahaan untuk jangka panjang. Konsumen cenderung memilih produk yang sudah dikenal baik atau memiliki citra merk yang baik. Mengingat pentingnya reputasi perusahaan sebagai aset tidak berwujud yang berharga 
yang harus dikelola perusahaan dengan hati-hati (Maden, 2012:662). Karena apabila suatu produk sudah memiliki citra yang positif, diyakini dapat memenuhi kebutuhan dan keinginan konsumen, maka minat beli masyarakat terhadap produk itu akan meningkat (Osiyo, 2018:8)

3. Mempengaruhi masyarakat untuk menjaga lingkungan.

Green Marketing secara tidak langsung memberi informasi dan atau pengetahuan kepada masyarakat mengenai lingkungan. Secara tidak langsung masyarakat mulai peka juga turut peduli akan masalah lingkungan dengan membeli green product atau dengan melihat iklan produk yang menggunakan strategi Green Marketing. Sebagian besar konsumen percaya bahwa Green Marketing akan baik untuk lingkungan dan dari segi kualitas juga kinerja memiliki nilai yang lebih dibanding produk lainnya (Arli dkk, 2018:396)

4. Menciptakan keunggulan kompetitif.

Perusahaan yang menerapkan strategi pemasaran hijau akan lebih mudah mendapatkan pangsa pasar karena konsumen yang memiliki kesadaran dan kepedulian yang tinggi terhadap lingkungan akan cenderung memilih produk yang memiliki kualitas dari segi kesehatan dan ramah lingkungan. Oleh karena itu konsumen akan melihat bentuk dan kualitas dari produk tersebut. Sehingga untuk mempertahankan jumlah konsumen perusahaan hanya perlu mempertahankan kualitas produk dan akan menjadi keunggulan kompetitif tersendiri (Septifani dkk, 2014:214).

\section{Hambatan Dalam Menerapkan Strategi Penerapan Komunikasi Pemasaran}

Penerapan strategi Green Marketing memiliki hambatan untuk bisa mengomunikasikannya melalui brand produk lokal, hal itu terdiri dari :

1. Perilaku adaptasi masyarakat kurang cepat.

Tidak semua masyarakat dapat beradaptasi dengan cepat, hal ini disebabkan konsep komunikasi pemasaran yang cenderung berkonsep lingkungan. Karena ada peluang di mana dalam melakukan proses promosi penjualan (sales promotion) terdapat tantangan dan rintangan tersendiri bagi perusahaan yaitu saat terjadinya pergantian posisi karyawan dalam divisi penjualan di perusahaan, sehingga supervisor sales dan executive sales harus mengadakan pelatihan mengenai klasifikasi produk ramah lingkungan yang akan dijual dan langkah-langkah promosi agar tidak bertentangan dengan konsep Green Marketing (Lestari, 2015:100).

2. Membutuhkan biaya yang lebih besar.

Investor belum tentu tertarik untuk berinvestasi kepada perusahaan yang berfokus pada perbaikan lingkungan dan kehidupan yang lebih baik. Alasannya karena mereka akan mengeluarkan biaya lebih untuk melakukan perbaikan lingkungan beserta peningkatan kualitas pada produknya.

3. Tidak dapat dipastikan semua pihak setuju dengan prinsip Green Marketing.

Dalam suatu organisasi internal akan terdapat sebuah tantangan saat melakukan komunikasi antara departemen satu dengan departemen lainnya karena adanya keanekaragaman watak dan sikap seorang pekerja yang dibentuk dari pengalaman dan latar belakang yang berbeda-beda. Tantangan komunikasi tersebut dapat menyebabkan perusahaan tidak serta merta langsung menerapkan Green Marketing (Jessica Gani, 2014:9)

\section{SIMPULAN}

\section{Simpulan}

Berdasarkan hasil penelitian dan pembahasan pada penelitian ini, maka dapat disimpulkan bahwa

a. Perilaku konsumen berpengaruh positif dan tidak signifikan terhadap minat beli produk lokal.

b. Promosi media sosial berpengaruh positif dan tidak signifikan terhadap minat beli produk lokal.

c. Green Marketing berpengaruh positif dan signifikan terhadap minat beli produk lokal.

d. Perilaku konsumen, promosi media sosial, dan Green Marketing secara bersama-sama berpengaruh signifikan terhadap minat beli produk lokal oleh masyarakat Indonesia. 
Dari hasil penelitian tersebut, maka strategi pemasaran sangat berpengaruh terhadap minat beli produk lokal. Green Marketing adalah strategi komunikasi pemasaran yang sangat tepat digunakan untuk meningkatkan minat beli produk lokal. Dalam penerapan green marketing, perlu dilakukan strategi komunikasi yaitu promosi produk lokal mengangkat isu-isu lingkungan mengenai kerusakankerusakan alam harus diperbaiki secara bersama-sama, menjual produk-produk ramah lingkungan terbaru dengan menggunakan potongan harga di dalam produk yang dijual secara langsung dan memberikan ucapan terima kasih terhadap produk yang telah dibeli, serta menciptakan gerakan yang masif dalam pembaharuan lingkungan dan mendukung produk-produk ramah lingkungan dengan melalui media digital. Oleh karena itu, penerapan Green Marketing ini perlu dilakukan secara bertahap untuk menghadapi hambatan-hambatan dan diharapkan dapat berdampak positif baik bagi pertumbuhan pasar produk lokal dan lingkungan.

\section{DAFTAR PUSTAKA}

Achmadi, C. N. (2008). Metodologi Penelitian. Jakarta: Bumi Aksara.

Agustin, R.D, Kumadji, S., Yulianto, E. (2015). Pengaruh Green Marketing Terhadap Minat Beli Serta Dampaknya Pada Keputusan Pembelian. Jurnal Administrasi Bisnis, 22, 110.

Arli, D., Tan, L. P., Tjiptono, F., \& Yang, L. (2018). Exploring consumers' purchase intention towards green products in an emerging market: The role of consumers' perceived readiness. International journal of consumer studies, 42(4), 389-401.

Badan Pusat Statistik. (2019). Buletin Statistik Perdagangan Luar Negeri Impor Mei 2019 Jakarta, DKI : Penulis. Diakses dari https:/www.bps.go.id/publication/2019/08/06/ 157bd9c8ab1c700ef64cc98d/buletin-statistik-perdagangan-luar-negeri-impor-mei2019.html.

Chrismardani, Y. (2014). Komunikasi Pemasaran Terpadu. Implementasi untuk UMKM, 179189.

Engel, J. F. (1973). Blackwell, consumer behavior. New York: Blackwell.

Gani, J. (2014). Pengaruh hambatan komunikasi terhadap kinerja karyawan hotel midtown surabaya. Jurnal E-Komunikasi, 02, 1-10.

Imon, W., Tumbel, A., \& Mandagie, Y. (2018). Analisis faktor yang mempengaruhi keberhasilan dan kegagalan pada strategi pemasaran toko sepatu payless cabang megamall. Jurnal EMBA, 06, 1308 -1317.

Kasali, R. (2005). Sembilan Fenomena Bisnis. Management Student Society. Jakarta : FEUI Official Site.

Kotler, P. D. (2008). Corporate social responsibility: Doing the most good for your company and your cause. John Wiley \& Sons.

Lestari, R. (2015). Sales promotion sebagai strategi komunikasi pemasaran mobil low cost green car daihatsu ayla pada pt. Astra internasional tbk cabang ciledugkota tangerang. Jurnal Ilmu Komunikasi, 03, 83-107.

Maden, C. A. (2012). Linking corporate social responsibility to corporate reputation: a study on understanding behavioral consequences. Procedia-Social and Behavioral Sciences, 655-664.

Osiyo, A. K. (2018). Pengaruh green marketing terhadap green brand image dan purchase intention pelanggan pada starbucks coffee malang. Jurnal Strategi Pemasaran, 1-9.

Pancoro, I.A. \& Zuliestiana, D. (2018). Pengaruh green marketing terhadap minat beli pada gerai starbucks di kota bandung. E-Proceeding Of Management, 05, 1886-1893.

Syahputra, I. (2013). Perspektif \& Teori Komunikasi. Yogyakarta: Galuh Patria. 
Septifani, R., Achmadi, F., \& Santoso, I. (2014). Pengaruh green marketing, pengetahuan dan minat membeli terhadap keputusan pembelian. Jurnal Manajemen Teknologi, 13, 201218.

Setiawan, E. (2014). Analisa Sikap Konsumen Terhadap Produk Fashion Lokal dan Impor. Jurnal Economia, 10, 38-47.

Siswanto (2017). Mencintai produk dalam negeri Sebagai Manifestasi Bela Negara di Era Global. Jurnal Pertahanan dan Bela Negara, 07, 85-105.

Sri Rahayu (2017). Strategi pemasaran hijau sebagai upaya meningkatan keunggulan bersaing. Jurnal Buletin Ekonomi, 2, 155-303.

Swastha, B. \&. (2000). Manajemen Pemasaran, Analisa Perilaku Konsumen. Yogyakarta: BPFE.

Triana, D. (2017). Analisis Pengaruh Green Marketing dan Store Atmosphere terhadap Emotional Response dan Dampaknya pada Impulse Buying.

Wisana, K.N.P. (2018). Pengaruh green marketing terhadap sikap konsumen dan minat beli ulang di green hotel di indonesia , 197-203 